\title{
Thyroid Status in Patients with Low Serum Ferritin Level
}

\author{
S Akhter1, ZU Nahar², S Parvin³ ${ }^{3}$ A Alam ${ }^{4}$, S Sharmin' 5 , MI Arslan² \\ ${ }^{1}$ Dept of Biochemistry, National Institute of Neurosciences (NINS), Dhaka \\ 2Dept of Biochemistry, Bangabandhu Sheikh Mujib Medical, University, (BSMMU), Dhaka \\ ${ }^{3}$ Dept of Biochemistry, Sir Salimullah Medical College, Dhaka \\ ${ }^{4}$ Dept of Biochemistry, Green Life Medical College, Dhaka \\ ${ }^{5}$ Dept of Biochemistry, Holy Family Red Crecent Medical college, Dhaka
}

\begin{abstract}
Iron deficiency is the most important but preventable nutritional problem in Bangladesh. Thyroid peroxidase, an iron containing enzyme, is essential for initial two steps of thyroid hormone synthesis which is a component of tissue iron. Tissue iron diminishes early in the course of iron deficiency. So thyroid hormone level may be altered in iron deficient patients. This case-control study was carried out in the Department of Biochemistry, Bangabandhu Sheikh Mujib Medical University (BSMMU) from July 2006 to June 2007. This study was done to find out the changes of thyroid hormonal activity in iron deficiency.

In this study 72 subjects were selected from the out-patient department of the hospital. Patients with low serum ferritin level $<12 \mu \mathrm{gm} / \mathrm{L}$ were selected as cases $(n=36)$ and healthy persons with normal serum ferritin level were taken as controls. Serum ferritin, thyroid stimulating hormone $(\mathrm{TSH})$, free thyroxine $\left(\mathrm{FT}_{4}\right)$ and free triiodothyronine $\left(\mathrm{FT}_{3}\right)$ were measured in all study subjects. Values were expressed as mean \pm SD. Unpaired ' $t$ ' test and Pearson's correlation test were performed to see the level of significance and $p$ value $<0.05$ was taken as significant. Serum ferritin level in cases and controls were $6.78 \pm 4.05 \mu \mathrm{gm} / \mathrm{L}$ and $79.04 \pm 28.08 \mu \mathrm{gm} / \mathrm{L}$ respectively which showed significant difference $(\mathrm{P}<0.0001)$.
\end{abstract}

Serum TSH concentration in cases and controls were $3.32 \pm 1.54 \mathrm{mIU} / \mathrm{L}$ and $1.89 \pm 0.86$ $\mathrm{mIU} / \mathrm{L}$ respectively. Serum $\mathrm{FT}_{4}$ concentration in cases and controls were $11.66 \pm 1.77$ $\mathrm{pmol} / \mathrm{L}$ and $13 / 10 \pm 1.36 \mathrm{pmol} / \mathrm{L}$ respectively and that of $\mathrm{FT}_{3}$ were $3.00 \pm 0.68$ and $3.31 \pm 0.61 \mathrm{pmol} / \mathrm{L}$ respectively. All showed significant difference between groups.

Serum ferritin and Serum TSH showed significant negative correlation in controls whereas in cases they showed negative correlation which was not statistically significant.

Both serum $\mathrm{FT}_{4}$ and $\mathrm{FT}_{3}$ revealed positive correlation with serum ferritin but that too was not significant statistically.

Though the study failed to show any significant positive correlation between serum ferritin and thyroid hormones, lower level of thyroid status in iron deficient patients suggest that it could be a reflection of disturbed activities of iron dependent enzymes such as thyroid peroxidase that impairs thyroid hormone synthesis. However, a large scale study is recommeded to establish the fact.

This study showed that there was significant difference in thyroid hormonal status between iron deficient patients and normal healthy persons. Therefore it can be concluded that iron deficiency may impair normal thyroid hormone status.

Key words: Thyroid peroxidase, Ferritin, $\mathrm{TSH}, \mathrm{FT}_{4}, \mathrm{FT}_{3}$ 


\section{Introduction}

Several minerals and trace elements like iodine, iron, selenium and zinc are essential for normal thyroid hormone metabolism. Iron deficiency impairs thyroid hormone synthesis by reducing activities of heme-dependent thyroid peroxidase. Iron deficiency anemia blunts and iron supplementation improves the efficacy of iodine supplementation ${ }^{1}$.

Thyroid peroxidase (TPO) is a membrane-bound glycosylated hemoprotein that plays a key role in the biosynthesis of thyroid hormones. This enzyme is responsible for the oxidation of iodide and binding of iodine to tyrosyl residue of thyroglobulin (organification). Two diiodotyrosine (DIT) molecules undergo an oxidative condensation for the formation of thyroxine $\left(T_{4}\right)$. Tri-iodothyronine $\left(T_{3}\right)$ is yielded from the coupling of one mono-iodotyrosine (MIT) and one di-iodotyrosine (DIT). A separate coupling enzyme has not been found and since this is an oxidative process, it is assumed that same thyroperoxidase catalyzes this reaction. This hypothesis is supported by observation that the same drug which inhibits iodide oxidation also inhibits coupling 2 .

Iron deficiency has been reported to impair the body's ability to make its own thyroid hormone which could increase need for thyroid medication. In a preliminary trial, iron supplementation given to iron deficient women with low blood levels of thyroid hormones, partially normalized these levels ${ }^{3}$. The degree of iron deficiency was found to affect thyroid hormone status in iron-deficient adolescent Iranian girls ${ }^{4}$.

Under normal circumstances iron absorption slightly exceeds iron excretion. The daily iron requirement for hemoglobin synthesis is 20-25 $\mathrm{mg}$. Body conserves its iron stores by reutilizing the iron derived from the breakdown of the hemoglobin from aged red cells. Progressive depletion and ultimate exhaustion of available tissue iron stores is followed by the development of anemia. It has been estimated that, 20 percent of the world's population is iron deficient and iron deficiency anemia is the most common type of anemia. Iron deficiency is defined by the coexistence of serum transferrin saturation less than $16 \%$ and a serum ferritin level less than 15 $\mu \mathrm{g} / \mathrm{L}$. Anemia is defined as a hemoglobin level of $115 \mathrm{gm} / \mathrm{L}$ or less in women and $135 \mathrm{gm} / \mathrm{L}$ or less in men ${ }^{5}$.

Iron deficiency is the most common preventable nutritional deficiency in the world especially among infants and young children in developing countries. Its associated anemia is linked with depressed mental and motor development during infancy and early childhood which may be irreversible. In South Asia the prevalence of iron deficiency anemia (IDA) among children under 5 years of age is estimated to be $75 \%$, $55 \%$, and $56 \%$ in India, Bangladesh and Pakistan respectively ${ }^{6}$.

Anemia is a frequent finding in infants with congenital hypothyroidism and is dependent on the degree of neonatal hypothyroidism which imply that during development hypothyroidism may produce persisting changes even after thyroid replacement has begun ${ }^{7}$. Since iron deficiency is present before the onset of anemia, detection of an iron depleted state is important for the control of nutritional anemia ${ }^{8}$.

Plasma ferritin is a measure of iron stores and the best single test to confirm iron deficiency. Low hemoglobin concentration is most readily available sign of anemia, but a significant fall in circulating hemoglobin cannot be detected until the final stage of iron deficiency ${ }^{9}$.

The prevalence of primary hypothyroidism is $1: 100$, but increases to $5: 100$ if patients with sub-clinical hypothyroidism are included. The female: male ratio is approximately $6: 1^{10}$.

Iron supplementation improves the efficacy of iodized salt in goitrous children with iron deficiency in Cote d'Ivoire ${ }^{11}$. An interventional study in goitrous, iron deficient anemic children showed that iron supplementation may improve the efficacy of oral iodized oil ${ }^{12}$. An interventional double blind controlled trial with dual fortified salt containing iodine and micro-encapsulated iron in 
northern Moroccan school children showed that a dual fortified salt can be an effective fortification strategy ${ }^{13}$.

In our country, the prevalence of both iron deficiency anemia and hypothyroidism are higher than other developed countries. Due to ignorance and carelessness, many overt hypothyroid and sub-clinical hypothyroid patients remain undiagnosed. Our study was designed to see the status of thyroid hormone in patients with low ferritin level. Iron deficient patients were diagnosed by serum ferritin level $<12 \mu \mathrm{g} / \mathrm{L}$ irrespective of age and sex. Iron deficiency anemia is an advanced stage of iron depletion. Complete treatment of iron deficiency anemia (IDA) will decrease the prevalence of iron deficiency and also decrease the burden of hypothyroidism from society. A cross sectional study on children of iron deficiency in iran showed that iron deficiency is associated with high prevalence of goiter in Iranian school children ${ }^{14}$.

Therefore the present case-control study was designed to find out the relationship of thyroid hormone status with iron deficient patients in Bangladeshi population.

\section{Materials \& Methods}

This case-control study was carried out from July 2006 to June 2007 in the Department of Biochemistry, Bangabandhu Sheikh Mujib Medical University (BSMMU), Dhaka. In this study total 72 subjects were selected from out patient department of the hospital. Patients with low serum ferritin level (serum ferritin level $<12 \mu \mathrm{g} / \mathrm{L}$ irrespective of age and sex) were considered as cases and healthy persons with normal serum ferritin level16 (serum ferritin level in male is $30-300 \mu \mathrm{g} / \mathrm{L}$ and in female is $20-120 \mu \mathrm{g} / \mathrm{L}$ ) was considered as controls. Patients having pregnancy, known iodine deficiency, positive for Anti-TPO and Anti-TG, hepatic disorder and renal diseases were excluded from the study. Relevant informations- collected from history, physical findings and laboratory investigations were recorded in predesigned data sheet. The whole procedure was explained to each patient and a written consent was taken from him or his attendant. Permission was taken from the concerned Ethical Committee.

With all aseptic precautions $5 \mathrm{ml}$ of morning blood were collected from the median cubital vein of all study subjects by disposable plastic syringe. The needle was detached from the nozzle and blood was transferred immediately into dry clean plastic test tubes and was allowed to clot. Then the test tube was centrifuged. Separated serums were collected into plastic micro centrifuge tubes were labeled appropriately and were stored in ultra freezer at $-35^{0} \mathrm{C}$ until analysis. Spot urine was collected in dry clean test tubes for estimation of urinary iodine.

Unpaired t-test and Pearson's correlation test were performed. Level of significance was expressed as $\mathrm{p}$ value. $\mathrm{P}$ value of $<0.05$ was considered as significant.

\section{Results \& Observations}

To evaluate the thyroid hormone status in iron deficient patient a total of seventy two subjects of both sexes were selected for this study of which thirty six were iron deficient patients (male-14 and female-22) and thirty six were normal healthy controls (male-14 and female22). Mean \pm SD of age among cases and controls were $32.75 \pm 10.36$ and $34.69 \pm 12.24$ years with the range of 16-60 years and 15-60 years respectively. There was no significant difference with respect of age distribution in cases and controls $(p>0.05)($ Table I).

Mean \pm SD values of serum ferritin concentrations in cases and controls were $6.78 \pm 4.05 \mu \mathrm{g} / \mathrm{L}$ and $79.04 \pm 28.08 \mu \mathrm{g} / \mathrm{L}$ respectively. There was highly significant difference of serum ferritin between cases and controls $(p<0.001)$ (Table II, Fig 1).

Mean \pm SD of serum TSH concentrations in cases and controls were $3.32 \pm 1.54 \mathrm{mIU} / \mathrm{L}$ and $1.89 \pm 0.86 \mathrm{mIU} / \mathrm{L}$ respectively. Mean $\pm \mathrm{SD}$ of 
serum $\mathrm{FT}_{4}$ concentration in cases and controls were $11.66 \pm 1.77 \mathrm{pmol} / \mathrm{L}$ and $13.10 \pm 1.36$ $\mathrm{pmol} / \mathrm{L}$ respectively. Mean $\pm \mathrm{SD}$ of serum $\mathrm{FT}_{3}$ in case and controls were $3.00 \pm 0.68 \mathrm{pmol} / \mathrm{L}$ and $3.31 \pm 0.61 \mathrm{pmol} / \mathrm{L}$ respectively (Table III).

Serum TSH concentrations between cases and controls showed highly significant difference $(p<0.001)$. Serum $\mathrm{FT}_{4}$ concentration. between cases and controls showed highly significant difference $(p<0.001)$. There was significant difference of serum $\mathrm{FT}_{3}$ between case and controls $(\mathrm{p}<0.05)$ (Table III).

Table I: Comparison of age in cases and controls

Group Mean \pm SD "t" value $\quad p "$ value

Case

$(\mathrm{n}=36) \quad 32.75 \pm 10.36$

$0.737>0.05^{*}$

$(\mathrm{n}=36) \quad 34.69 \pm 12.24$

* No significant difference.

Table II: Serum ferritin concentrations in study subjects

\begin{tabular}{|c|c|c|c|}
\hline Group & $\begin{array}{c}\text { S. Ferritin }(\mu \mathrm{g} / \mathrm{L}) \\
\text { Mean } \pm \mathrm{SD}\end{array}$ & t" value & "p" value \\
\hline Case $(n=36)$ & $6.78 \pm 4.05$ & 15.28 & $<0.001 *$ \\
\hline Control $(\mathrm{n}=36)$ & 6) $79.04 \pm 28.08$ & & \\
\hline
\end{tabular}

* Highly significant difference

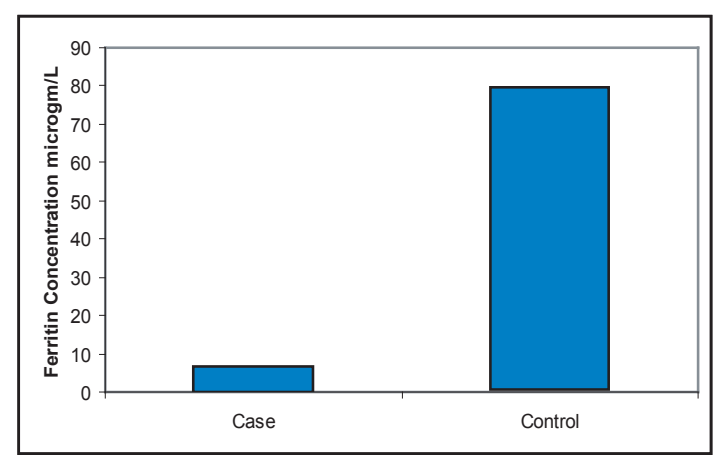

Fig 1: Serum ferritin concentrations in study subjects

S Akhter, ZU Nahar, S Parvin, A Alam et al

Table III: Comparison of serum $\mathrm{TSH}, \mathrm{FT}_{4}$ and $\mathrm{FT}_{3}$ concentration in study subjects.

\begin{tabular}{lcccc}
\hline Parameters & $\begin{array}{c}\text { Case } \\
(\mathrm{n}=36)\end{array}$ & $\begin{array}{c}\text { Control } \\
(\mathrm{n}=36)\end{array}$ & "t" value & "P" value \\
\hline $\begin{array}{l}\text { TSH mIU/L } \\
\text { Mean } \pm \text { SD }\end{array}$ & $3.32 \pm 1.54$ & $1.89 \pm 0.86$ & 4.87 & $<0.001 \mathrm{HS}$ \\
FT4 pmol/L & & & & \\
Mean \pm SD & $11.66 \pm 1.77$ & $13.10 \pm 1.36$ & 3.88 & $<0.001 \mathrm{HS}$ \\
FT3 pmol/L & $3.00 \pm 0.68$ & $3.31 \pm 0.61$ & 3.51 & $<0.05 *$ \\
Mean $\pm \mathrm{SD}$ & $3.00 \pm 0$
\end{tabular}

\section{HS: Highly significant difference}

Serum ferritin and serum TSH in control subjects revealed that there was significant negative correlation ( $\mathrm{r}$ was $-0.480, \mathrm{p}<0.01$ ). In iron deficient patients there was negative correlation between serum ferritin and serum TSH but it was not statistically significant ( $\mathrm{r}$ was -0.224 and $p>0.05$ ) (Table IV, Fig: $2 \& 3$ ).

Serum ferritin and serum $\mathrm{FT}_{4}$ concentrations in iron deficient patient revealed positive correlation but not statistically significant ( $\mathrm{r}$ was 0.273 and $p>0.05$ ). Serum ferritin and serum $\mathrm{FT}_{4}$ concentration in controls also showed positive correlation but that was not statistically significant ( $\mathrm{r}$ was 0.211 and $\mathrm{p}>0.05$ ) (Table $\mathrm{V}$, Fig: 4 \& 5).

There was no significant correlation between serum ferritin and serum $\mathrm{FT}_{3}$ concentration in cases ( $\mathrm{r}$ was 0.033 and $\mathrm{p}>0.05$ ). There was also no significant correlation between serum ferritin and serum $\mathrm{FT}_{3}$ level in controls ( $\mathrm{r}$ was 0.101 and $\mathrm{p}>0.05$ ) (Table VI, Fig: $6 \& 7$ ).

Table VI: Correlation between serum Ferritin and TSH in study subjects.

\begin{tabular}{lcccc}
\hline Group & $\begin{array}{c}\text { S. Ferritin } \\
\text { Mean } \pm \text { SD } \\
\mu \mathrm{g} / \mathrm{L}\end{array}$ & $\begin{array}{c}\text { S. TSH } \\
\text { Mean } \pm \text { SD } \\
\mathrm{pmol} / \mathrm{L}\end{array}$ & "r" value & "p" value \\
\hline $\begin{array}{l}\text { Case } \\
(\mathrm{n}=36)\end{array}$ & $6.78 \pm 4.05$ & $3.32 \pm 1.54$ & -0.224 & $>0.05^{*}$ \\
$\begin{array}{l}\text { Control } \\
(\mathrm{n}=36)\end{array}$ & $79.04 \pm 28.08$ & $1.89 \pm 0.86$ & -0.480 & $<0.01$ \\
\hline
\end{tabular}


Thyroid Status in Patients with Low Serum Ferritin

Table V: Correlation between serum Ferritin and $\mathrm{FT}_{4}$ in study subjects

\begin{tabular}{lcccc}
\hline Group & $\begin{array}{c}\text { S. Ferritin } \\
\text { Mean } \pm \text { SD } \\
\mu \mathrm{g} / \mathrm{L}\end{array}$ & $\begin{array}{c}\mathrm{S} . \mathrm{FT}_{4} \\
\mathrm{Mean} \pm \mathrm{SD} \\
\mathrm{pmol} / \mathrm{L}\end{array}$ & "r" value & "p" value \\
\hline $\begin{array}{l}\text { Case } \\
(\mathrm{n}=36)\end{array}$ & $6.78 \pm 4.05$ & $11.66 \pm 1.77$ & +0.273 & $>0.05^{*}$ \\
$\begin{array}{l}\text { Control } \\
(\mathrm{n}=36)\end{array}$ & $79.04 \pm 28.08$ & $13.10 \pm 1.36$ & +0.211 & $>0.05^{*}$ \\
\hline
\end{tabular}

* Not statistically significant difference.

MS: Moderately significant difference.

Table VI: Correlation between serum Ferritin and $\mathrm{FT}_{3}$ in cases and in controls.

\begin{tabular}{lcccc}
\hline Group & $\begin{array}{c}\text { S. Ferritin } \\
\text { Mean } \pm \text { SD } \\
\mu \mathrm{g} / \mathrm{L}\end{array}$ & $\begin{array}{c}\mathrm{S} . \mathrm{FT}_{3} \\
\text { Mean } \pm \mathrm{SD} \\
\mathrm{pmol} / \mathrm{L}\end{array}$ & "r" value & "p" value \\
\hline Case & $6.78 \pm 4.05$ & $3.00 \pm 0.68$ & +0.033 & $>0.05^{*}$ \\
Control & $79.04 \pm 28.08$ & $3.31 \pm 0.61$ & +0.101 & $>0.05^{*}$
\end{tabular}

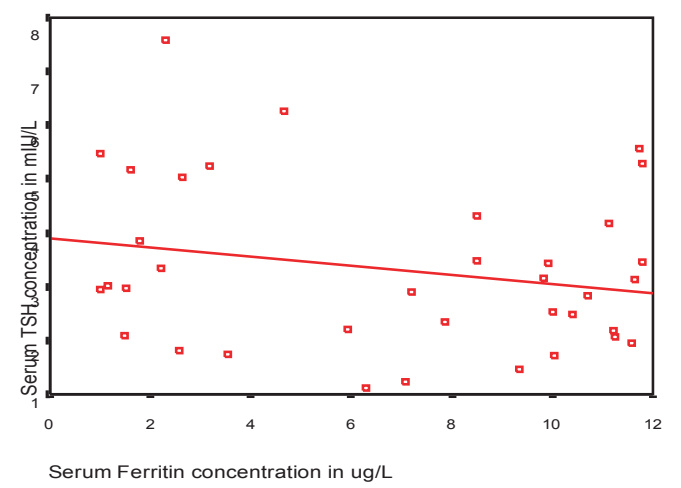

Fig 2: Correlation of serum ferritin with serum TSH concentrations in cases.

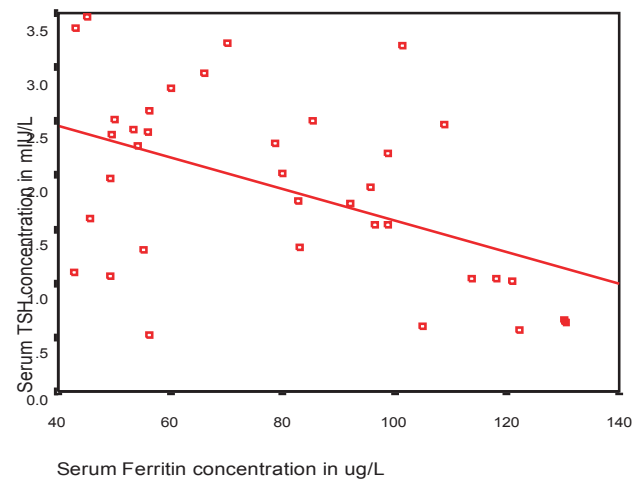

Fig 3: Correlation of serum ferritin with serum TSH concentrations in controls.

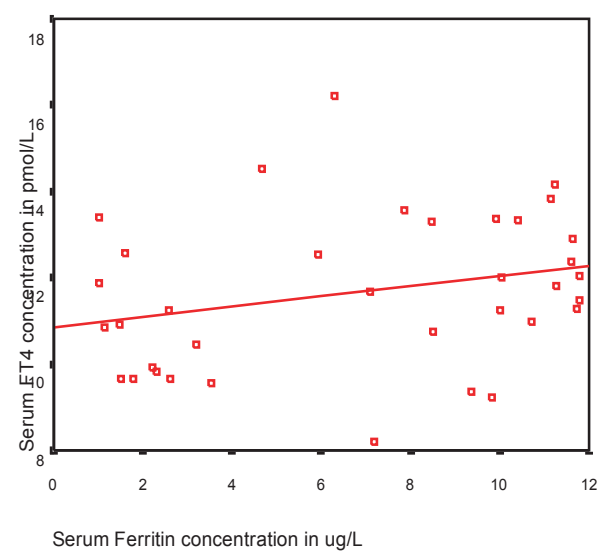

Fig 4: Correlation of serum ferritin with $\mathrm{FT}_{4}$ concentrations in cases.

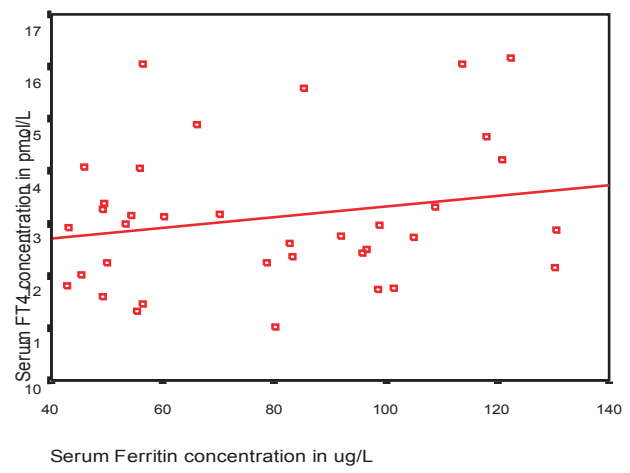

Fig 5: Correlation between serum ferritin and serum $\mathrm{FT}_{4}$ concentrations in controls.

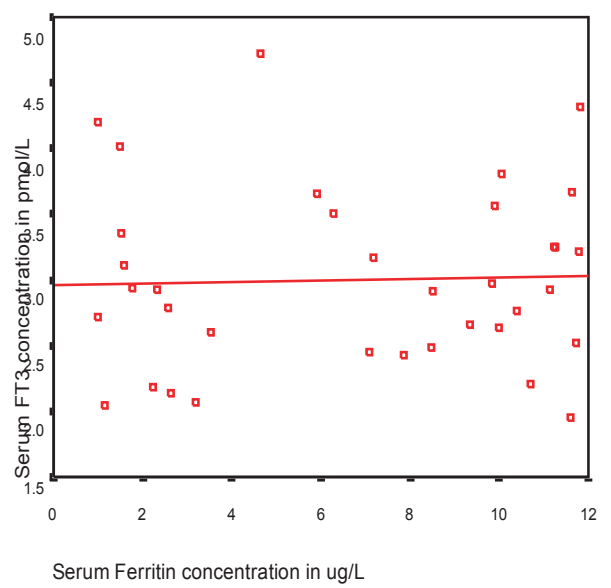

Fig 6: Correlation of serum ferritin with $\mathrm{FT}_{3}$ concentrations in cases. 


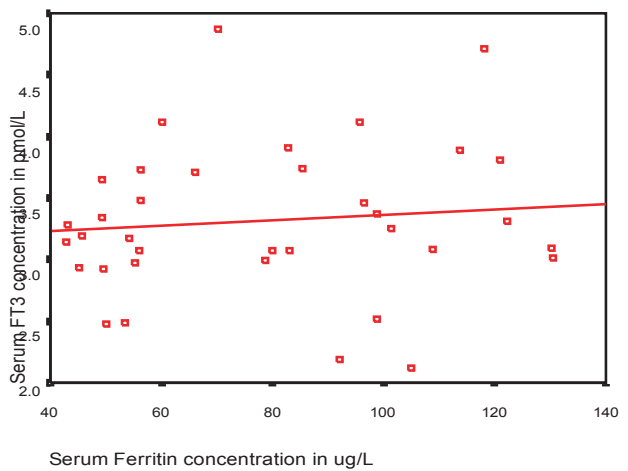

Fig 7: Correlation between serum ferritin and serum $\mathrm{FT}_{3}$ concentrations in controls.

\section{Discussion}

In this case control study to find out the relationship between iron deficiency and thyroid hormone status, we have measured the serum $\mathrm{FT}_{3}, \mathrm{FT}_{4}$ and $\mathrm{TSH}$ level in iron deficient patients having low serum ferritin level and in healthy controls. It is observed in this study that the serum $\mathrm{FT}_{4}$ level was significantly lowered in cases than that of controls $(p<0.001)$. This study is consistent with Beard, Borel and Derr ${ }^{3}$. They showed that free $\mathrm{T}_{4}$ concentrations were significantly lower in iron deficient anemia than normal healthy person and correction of anemia with iron supplementation increases free $T_{4}$ levels. Our study also consistent with Etekhari, Keshavarz and Jalali et al.15 They showed that depletion of iron stores may decrease serum free $\mathrm{T}_{4}$ level. There was statistical significant positive correlation between serum ferritin and free $\mathrm{T} 4$ in our study group. It was consistent with the study done by Eftekhari, Keshavarz and Jalali et al15. They had showed that there was positive significant correlation between serum ferritin and free $T_{4}$.

This study revealed that serum free $T_{3}$ concentrations were significantly lowered in iron deficient patients compared to healthy controls $(\mathrm{p}<0.05)$. It was consistent with the study done by Beard, Borel and Derr ${ }^{3}$. They revealed that there was significant difference of serum free $\mathrm{T}_{3}$ between iron deficient and healthy control subjects.
Our study showed that the serum TSH levels were within lower level of normal reference range in healthy subjects. But in iron deficient patients the serum TSH level were at upper limit of normal reference range. It is observed that serum TSH concentrations were significantly higher in cases compared to controls $(p<0.001)$. This result is consistent with the study by Blum and Blum 16 . They showed that TSH level were significantly higher in the iron deficient group than the control though they remained within normal range. Our study showed that there was negative correlation of serum ferritin with serum TSH in iron deficient patients but that was not statistically significant $(p>0.05)$. There was significant negative correlation between serum ferritin and serum TSH in controls $(\mathrm{p}<0.05)$.

Discrepant views had been shown by some studies that the thyroid profile was not significantly affected in iron deficient patients. The survey in Turkey by Yavuz et al ${ }^{17}$ showed no correlation between iron status and thyroid hormone levels in school children. Another study in Thailand by Tienboon and Unachak ${ }^{18}$ showed that the thyroid hormones of IDA children before and after iron treatment were not significantly different from the control children. These variations may be due to different geographic distribution and different demographic characteristics of patients under study.

Our study suggested that the significant difference in thyroid hormone status in iron deficient people could be a reflection of disturbed activities of iron depended enzymes such as thyroid peroxidase that impairs thyroid hormone metabolism.

\section{References}

1. Zimmermann MB and Kohrle J. The Impact of Iron and Selenium Deficiencies on lodine and Thyroid metabolism: Biochemistry and Relevance to Public Health. N Eng J Med 2002; 12(10): 867-878

2. Granner DK. The diversity of the endocrine System, in RK. Murray, DK Granner, PA Mayes, \& VW Rodwell (eds), Harper's Illustrated Biochemistry, 26th edn, McGraw-Hill, United States 2003; 434-455. 
Thyroid Status in Patients with Low Serum Ferritin

3. Beard JL, Borel MJ and Derr J. Impaired thermoregulation and thyroid function in irondeficiency anemia. Am J Clin Nutr 1990; 52: 813-819.

4. Etfekhari MH, Keshavarz SA, Jalali M, Elguero E, Eshraghian MR and Simondon KB. The relationship between iron status and thyroid hormone concentration in iron deficient adolescent Iranian girls. Asia Pacific J Clin Nutr 2006; 15(1): 50-55.

5. Gruchy D. 'Hypochromic Anemia: Iron Deficiency and Sideroblastic Anaemia', 2005, in F, Firkin, C, Chesterman, D, Penington, \& B, Rush, (eds.) de Gruchy`s Clinical Hematology in Medical Practice, 5th edn Blackwell Science Ltd, London, pp.37-61.

6. Z1otkin SH, Christofides AL, Ziauddin HSM, Schauer CS, Tondeur MC and Sharieff W. Symposium on Micronutrient Deficiency Disorders. Ind J Pediat 2004; 71(11): 1015-1019

7. Franzese A, Salerno M, Argenziano A, Buongiovvanni $\mathrm{C}$, Limauro $\mathrm{R}$ and Tenore $\mathrm{A}$. Anemia in infants with congenital hypothyroidism, diagnosed neonatal screening. J Endocrinol Invest 1996; 19(9): 613-619.

8. Fairbanks VF and Beutler E. 'Iron Deficiency', in Williams, WJ (ed.), Hematology, McGraw Hill Book Co, New York, 1977, pp.363-387.

9. Craig JIO, McClelland DBL and Ludlam CA. Blood Disorders in NA Boon, NR Colledge, BR Walder \& JAA Hunter (eds.), Davidson's Principles and Practice of Medicine, 20th edn, Churchill Livingstone Elsevier, Philadelphia 2006; 999-1064

10. Strachan MW and Walder BR. Endocrine Disease in NA Boon, R Colledge, BR Walker \& JAA Hunter (eds), Davidson's Principles and Practice of Medicine, 20th edn, Churchill Livingstone, Elsevier Philadelphia 2006; 739-804.
11. Hess SY, Zimmermann MB, Adou P, Torresani T and Hurrell RF. Treatment of iron deficiency in goitrous children improves the efficacy of iodized salt in Cote d'Ivoire. Am J Clin Nutr 2002; 75(4):743-748.

12. Zimmermann $\mathrm{M}$, Adou $\mathrm{P}$, Torresani $\mathrm{T}$, Zeder $\mathrm{C}$ and Hurrell R. Iron supplementation in goitrous, irondeficient children improves their response to oral iodized oil. Eur J Endocrinol 2000; 142(3): 217-223.

13 Zimmermann MB, Zeder C, Chauki N, Torresani T, Saad A and Hurrell, RF. 'Addition of microencapsulated iron to iodized salt improves the efficacy of iodine in goitrous, iron-deficient children: a randomized, double-blind, controlled trial. Eur J Endocrinol 2003;147;747-753.

14 Azizi F, Mirmiran P, Sheikholeslum R, Hedayati M and Rastmanesh $\mathrm{R}$. The relation between serum ferritin and goiter, urinary iodine and thyroid hormon. Int J Vit Nutr Res 2002; 72: 296-299.

15 Eftekhari MH, Keshavarz SA, Jalali M, Saadat N, Eshraghian MR. 'Thyroid hormones status in iron deficient adolescent girls'. Iran J Med Sc 2003;28(4);161-165.

16 Blum $\mathrm{M}$ and Blum G. The possible relationship between menorrhaegia and occult hypothyroidism in IUD wearing women. Advances in Contraception Journal 1992; 8: 313-317.

17 Yavuz O, Yuvaz T, Kahraman C, Yesildal N and Bundak R. The relationship between iron status and thyroid hormones in adolescents, living in an iodine deficient area. J ped Endocrin Metabol 2004; 17(10): 1443-1449.

18 Tienboon $\mathrm{P}$ and Unachak K. Iron deficiency anaemia in childhood and thyroid function. Asia Pacific J Clin Nutr 2003; 12(2): 198-202. 